\title{
KARAKTERISTIK MATAAIR KAKI LERENG GUNUNG MERAPI DAN PEMANFAATANNYA DI KECAMATAN DUKUN KABUPATEN MAGELANG
}

\author{
Oleh: \\ Ririn Putri Aurita ${ }^{1}$, Suhadi Purwantara ${ }^{2}$ \\ ${ }^{1}$ Mahasiswa Jurusan Pendidikan Geografi FIS UNY \\ ${ }^{2}$ Staf Pengajar Jurusan Pendidikan Geografi FIS UNY \\ auritaputri@gmail.com
}

\begin{abstract}
Abstrak
Penelitian ini dilaksanaan di Kecamatan Dukun Kabupaten Magelang dengan tujuan: (1) Mendekripsikan pola sebaran mataair; (2) Mengetahui potensi, pemanfaatan, dan imbangan antara potensi dan pemanfaatan mataair; (3) Membandingkan kualitas fisik dan kimia mataair pada bentuklahan dataran kaki gunungapi dan dataran fluvial gunungapi berdasarkan persyaratan baku mutu air minum menurut Permenkes RI nomor 492 tahun 2010. Populasi dalam penelitian ini terdiri atas fenomena fisik dan fenomena non fisik. Sampel diambil dengan purposive sampling untuk mataair; area probability sampling untuk kebutuhan air irigasi; dan random sampling untuk rumah tangga pengguna. Data dikumpulkan dengan observasi, wawancara dan dokumentasi. Hasil penelitian: (1) Sebaran mataair berdasarkan "nearest neighbour analysis" berpola mengelompok. (2) Terdapat 33 mataair untuk kebutuhan rumah tangga dan 8 mataair untuk irigasi. Debit terendah 0,16 liter/detik dan tertinggi 16 liter/detik. Rata-rata debit untuk rumah tangga 1,6 liter/detik dan irigasi 13,88 liter/detik. Pemanfaatan mataair untuk kebutuhan rumah tangga tercukupi dan rata-rata imbangan airnya surplus. Pemanfaatan untuk irigasi secara keseluruhan juga tercukupi, namun pada bulan Mei mengalami kekurangan air di Desa Paten. (3) Kualitas fisika dan kimia mataair sesuai dan memenuhi persyaratan kualitas air minum.
\end{abstract}

Kata kunci: Karakteristik Mataair, Kaki Lereng Gunung Merapi, Kecamatan Dukun

\begin{abstract}
This research was conducted in Dukun Subdistrict, Magelang Regency. The objectives are: (1) describing the distribution pattern of springs, (2) investigating the potential, utilization, and balance of springs, (3) comparing the physical and chemical quality of spring on landform of volcanic foot plain and volcanic fluvial plain based on the required standard of drinking water quality issued by the Minister of Health of Indonesia No. 492 of 2010. The population consisted of physical and non-physical phenomena. Samples were taken utilizing a purposive sampling technique for springs, an area probability sampling technique for irrigation needs, and a random sampling technique for households water needs. The data were collected through observations, interviews, and documentations. The results are: (1) the distribution of springs based on "nearest neighbor analysis" shows a clustered pattern. (2) there are 33 springs for water needs of households and 8 springs for irrigation. The lowest discharge is 0.16 liter/sec and the highest is 16 liter/sec. The average discharge for household is 1.6 liter/sec and for irrigation is 13.88 liter/sec. The springs for fulfilling household needs is sufficient and the average water balance is in surplus. Also, the springs for irrigation are adequate, but
\end{abstract}


there are shortages on May, in Paten Village. (3) The quality of the physical and chemical springs has met the standard.

Keywords: Springs Characteristic, Merapi Volcano Foot Slope, Dukun sub-district

\section{PENDAHULUAN}

Kecamatan Dukun merupakan salah satu kecamatan yang terletak di wilayah Kabupaten Magelang, Provinsi Jawa Tengah. Sebagian besar wilayah Kecamatan Dukun tersusun atas bentuklahan vulkanik yang berada pada lereng bagian barat Gunung Merapi. Secara umum, formasi batuan di Kecamatan Dukun tersusun dari formasi Gunung Merapi Muda. Formasi Gunung Merapi Muda merupakan major aquifer yang memiliki permeabilitas baik sehingga banyak mataair yang muncul di wilayah tersebut. Mataair yang muncul tersebut pada umumnya membentuk pola seperti sabuk yang disebut dengan sabuk mataair (spring be/t). Santosa (2006) menjelaskan bahwa sabuk mataair muncul di sepanjang tekuk lereng (break of slope) yang terdapat pada lereng dan kaki vulkan. Kondisi ini tidak terlepas dari pengaruh faktor geologi yang berkaitan dengan material penyusun wilayah tersebut serta faktor geomorfologi yang memungkinkan munculnya mataair (Ashari, 2014).

Mataair di Kecamatan Dukun merupakan mataair bertipe perennial yang mengalir sepanjang tahun. Namun, beberapa tahun terakhir ini terus terjadi penurunan debit dari setiap mataair. Faktor penting yang memberikan dampak perubahan debit mataair tersebut adalah karena berkurangnya kawasan lindung sebagai daerah resapan air. Debit mataair tidak hanya sekedar berkurang, beberapa sumber mataair bahkan mengering dan mati pada saat musim kemarau. Jumlah lahan kritis yang meningkat juga menyebabkan hilangnya fungsi lahan sebagai media pengatur tata air. Hal tersebut menyebabkan bencana kekeringan melanda beberapa dusun di Kecamatan Dukun pada saat musim kemarau. Salah satu desa yang mengalami kekeringan pada saat musim kemarau adalah Desa Banyudono. Desa Banyudono hanya menggunakan satu sumber mataair untuk mencukupi kebutuhan air penduduk 5 dusun, yakni Dusun Talun Kidul, Dusun Sorobandan, Dusun Macanan, Dusun Karang, dan Dusun Sentran. Pada saat musim penghujan, debit mataair mampu mencukupi kebutuhan air, namun pada saat musim kemarau besar debit mataair berkurang sehingga tidak mampu mencukupi kebutuhan warga Desa Banyudono.

Sebagian besar desa di wilayah Kecamatan Dukun memiliki sumber mataair untuk mencukupi kebutuhan masing-masing setiap desa. Sumber mataair yang ada di setiap desa tersebut memiliki debit dan persebaran yang berbeda-beda. Di Kecamatan Dukun, ada desa yang setiap dusunnya memiliki mataair lebih dari satu, seperti di Desa Dukun yang setiap dusunnya memiliki sumber mataair masing-masing. Namun terdapat pula desa dengan sumber mataair terbatas, sehingga mengandalkan mataair yang ada di wilayah desa lain untuk memenuhi kebutuhannya. Hal tersebut menunjukkan bahwa datadata mengenai debitdan persebaran mataair dari setiap sumber-sumber mataair sangat diperlukan agar air dari sumber-sumber mataair tersebut dapat terdistribusi secara maksimal. 
Mataair yang terdapat di wilayah Kecamatan Dukun belum terdaftar dan terpetakan secara optimal. Dari data rekapitulasi mataair yang dikeluarkan oleh Dinas Pengelolaan Sumber Daya Air Provinsi Jawa Tengah, di Kecamatan Dukun hanya terdata 12 mataair yang tersebar di 6 desa, yakni Desa Wates, Desa Kalibening, Desa Paten, Desa Sengi, Desa Banyubiru, dan Desa Ketunggeng (Tabel 1). Berdasarkan hasil observasi, hampir setiap desa di wilayah Kecamatan Dukun memiliki sumber mataair. Hal ini memperlihatkan bahwa banyak potensi mataair yang belum diinventarisasikan. Oleh karena itu, pendataan mataair terutama dalam hal lokasi dan potensi debitnya sangat diperlukan dalam upaya pengoptimalan distribusi air dari setiap sumber-sumber mataair.

Tabel 1. Data Mataair Kecamatan Dukun

\begin{tabular}{|c|c|c|}
\hline No. & Nama Mataair & Desa \\
\hline 1 & Betik & Wates \\
\hline 2 & Tuk Sempan & Wates \\
\hline 3 & Tuk Petung & Wates \\
\hline 4 & Tuk Gondok & Kali Bening \\
\hline 5 & Tuk Ringin & Kali Bening \\
\hline 6 & Tuk Simbir & Kali Bening \\
\hline 7 & Tuk Laren & Paten \\
\hline 8 & Tuk Candi & Sengi \\
\hline 9 & Sanggrahan & Banyubiru \\
\hline 10 & Mangguan & Ketunggeng \\
\hline 11 & Tuk Mangguan & Ketunggeng \\
\hline 12 & Tuk Manggun & Ketunggeng \\
\hline
\end{tabular}

Sumber : Rekapitulasi Mataair Provinsi Jawa Tengah

Air dari sumber-sumber mataair yang terdapat di Kecamatan Dukun digunakan untuk berbagai macam pemanfataan, antara lain untuk irigasi pertanian dan kebutuhan air rumah tangga. Kebutuhan terhadap sumberdaya air secara langsung dikontrol oleh jumlah penduduk. Kebutuhan air untuk rumah tangga di Kecamatan Dukun juga terus meningkat dari waktu ke waktu sejalan dengan laju pertambahan jumlah penduduk yang terus meningkat (Tabel 2).

Tabel 2. Jumlah Laju Pertumbuhan Penduduk di Kecamatan Dukun

\begin{tabular}{|c|c|c|}
\hline Tahun & Jumlah Penduduk (jiwa) & Laju Pertumbuhan Penduduk (\%) \\
\hline 1980 & 37.733 & - \\
\hline 1990 & 38.269 & 1,411 \\
\hline 2000 & 40.424 & 5,478 \\
\hline 2011 & 43.219 & 6,085 \\
\hline 2012 & 43.487 & 1,054 \\
\hline 2015 & 44.878 & 1,044 \\
\hline
\end{tabular}

Sumber: Badan Pusat Statistik Kabupaten Magelang (2015)

Berdasarkan pengamatan dan wawancara singkat oleh peneliti, warga desa di Kecamatan Dukun yang bertempat tinggal di kaki lereng bagian atas hanya menggunakan mataair sebagai sumber air untuk memenuhi kebutuhan hidupnya seharihari. Hal tersebut dikarenakan sumur tidak dapat dibuat di daerah ini, sedangkan 
masyarakat yang bertempat tinggal di kaki lereng bagian bawah dapat menggunakan sumur sebagai tambahan sumber air. Namun, penggunaan air dari mataair tetap menjadi prioritas utama warga Kecamatan Dukun dalam memenuhi kebutuhan air rumah tangga sehari-hari.

Selain digunakan untuk memenuhi kebutuhan air rumah tangga, mataair di Kecamatan Dukun juga digunakan sebagai sumber air untuk mengairi lahan pertanian (irigasi). Walaupun sumber air irigasi lahan pertanian desa-desa di Kecamatan Dukun ada yang berasal dari sungai, namun ada pula desa dengan lahan pertanian yang hanya mengandalkan air dari sumber mataair. Pada beberapa desa yang terletak di lereng kaki bagian atas, seperti Desa Paten dan Desa Krinjing, mataair merupakan sumber air utama untuk mengairi lahan pertanian. Berdasarkan hasil pengamatan, mataair yang digunakan untuk irigasi di Desa Paten dan Desa Krinjing dibendung kemudian disalurkan melalui pipa-pipa menuju lahan-lahan pertanian. Mataair yang digunakan untuk memenuhi kebutuhan air irigasi tersebut rata-rata memiliki debit yang cukup besar, yakni 8 sampai 16 liter per detik.

Penelitian karakteristik mataair di suatu wilayah merupakan sesuatu yang penting dilakukan tidak hanya berhubungan dengan kuantitas mataair tetapi juga kualitas mataair yang dipergunakan penduduk untuk berbagai pemanfaatan. Kuantitas air berupa potensi air di suatu wilayah dikaitkan dengan kebutuhan air untuk keperluan rumah tangga, keperluan pengairan lahan pertanian, dan berbagai keperluan lainnya. Kualitas air di suatu wilayah juga dikaitkan dengan karakteristik lingkungan sekitarnya. Berdasarkan latar belakang tersebut, diperlukannya sebuah penelitian mengenai karakteristik mataair dan pemanfaatannya di Kecamatan Dukun, Kabupaten Magelang.

\section{METODE}

Penelitian ini merupakan penelitian deskriptif kuantitatif. Data-data dalam penelitian ini diambil dengan cara melakukan observasi atau survei di lapangan, wawancara, dan analisa laboratorium. Observasi dilakukan untuk mendapatkan data mengenai sebaran, debit, dan sampel mataair. Data pemanfaatan mataair untuk kebutuhan air irigasi juga didapatkan dengan cara melakukan observasi atau survei lapangan. Data pemanfaatan mataair untuk kebutuhan rumah tangga didapatkan dengan cara melakukan wawancara kepada penduduk yang ada di setiap desa di Kecamatan Dukun. Analisa laboratorium dilakukan untuk mendapatkan data mengenai kualitas mataair dari setiap parameter fisik dan kimia berdasarkan persyaratan baku mutu air minum menurut Permenkes RI Nomor 492 Tahun 2010. Informasi ini kemudian diuraikan secara deskriptif dengan pendekatan analisis kuantitatif.

Populasi dalam penelitian ini terdiri dari populasi fisik dan populasi non fisik. Populasi fisik dalam penelitian ini adalah seluruh titik-titik pemunculan mataair yang ada di Kecamatan Dukun Kabupaten Magelang. Populasi non fisik dalam penelitian ini adalah seluruh rumah tangga yang ada di Kecamatan Dukun, Kabupaten Magelang. Pengambilan sampel fisik berupa debit mataair diambil menggunakan metode pengambilan sampel bertujuan atau purposive sampling. Pengambilan sampel fisik berupa pemanfaatan 
mataair untuk kebutuhan irigasi menggunakan metode pengambilan sampel wilayah (area probability sample). Sedangkan pengambilan sampel non fisik berupa kebutuhan air rumah tangga dalam penelitian ini menggunakan metode random sampling. Analisis data yang digunakan ialah "nearest neighbour analysis", analisis debit metode volumentrik, analisis imbangan mataair untuk kebutuhan rumah tangga dan irigasi, serta analisis kualitas fisik dan kimia mataair.

\section{HASIL DAN PEMBAHASAN}

\section{Daerah Penelitian}

Kecamatan Dukun merupakan salah satu kecamatan yang berada di bagian timur Kabupaten Magelang. Secara astronomis, Kecamatan Dukun terletak antara 110 $01^{\prime} 51^{\prime \prime}$ -

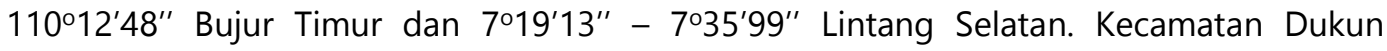
terbagi menjadi 15 wilayah desa, 145 dusun, 154 RW, dan 470 RT. Desa-desa di Kecamatan Dukun antara lain Desa Ketunggeng, Desa Ngadipuro, Desa Wates, Desa Kalibening, Desa Ngargomulyo, Desa Keningar, Desa Sumber, Desa Dukun, Desa Banyubiru, Desa Banyudono, Desa Mangunsoko, Desa Sewukan, Desa Krinjing, Desa Paten, dan Desa Sengi (Gambar 1). Kecamatan Dukun memiliki luas wilayah 53,41 km².

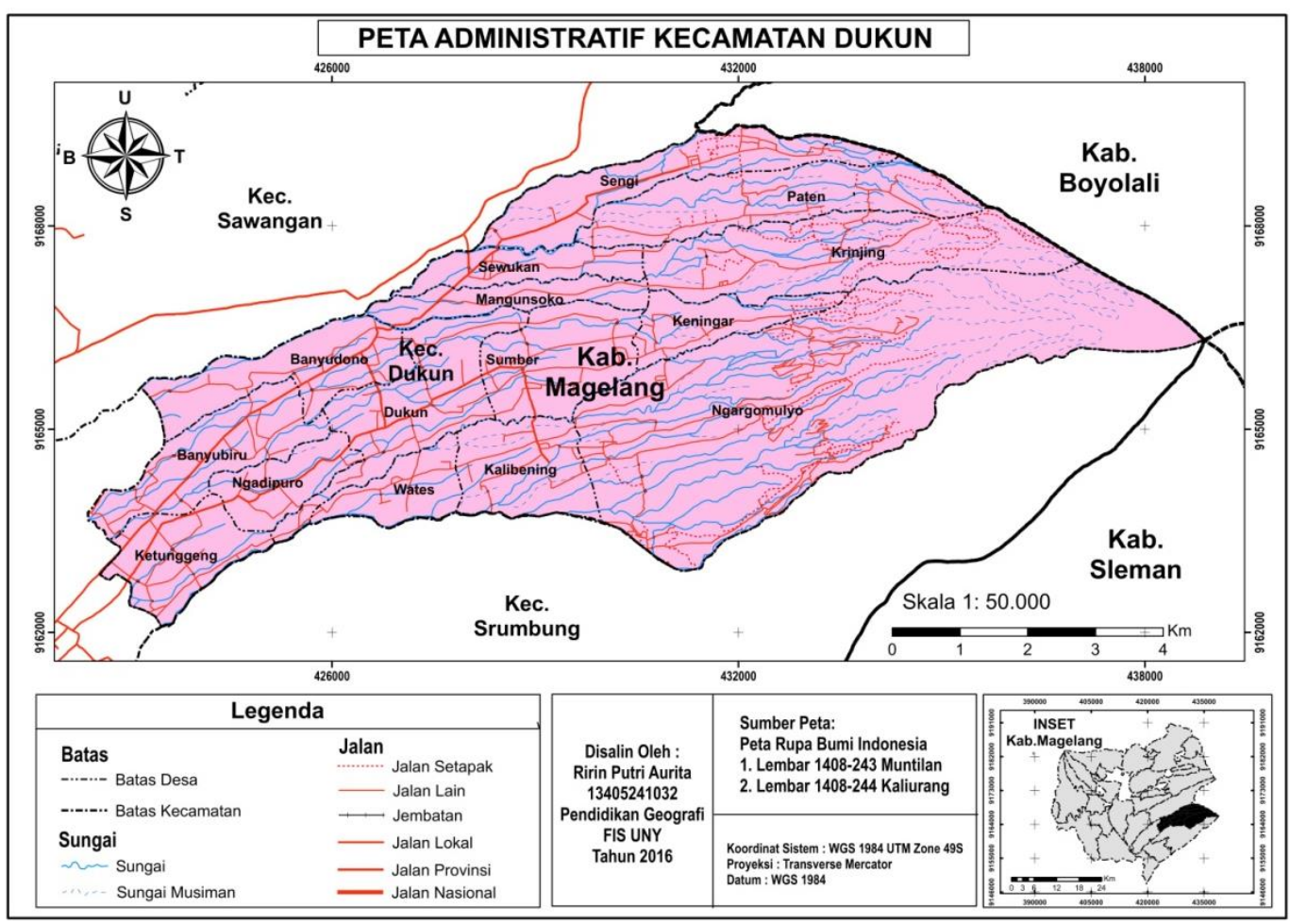

Gambar 1. Peta Administrasi Kecamatan Dukun

Iklim di Kecamatan Dukun terdiri dari golongan A (sangat basah) dan B (basah). Secara googis, Gunung Merapi memberikan pengaruh yang sangat besar terhadap kondisi geologi Kecamatan Dukun. Dalam peta Geologi Lembar Yogyakarta skala 1:100.000, kondisi geologis wilayah Kecamatan Dukun dapat dibagi menjadi lima, yakni 
batuan tak terpisahkan, endapan merapi tua, endapan merapi muda, endapan awan panas, serta kubah lava dan leleran.

\section{Pola Persebaran Mataair}

Penentuan nilai tetangga terdekat dalam penelitian ini menggunakan perangkat statistik spasial pada ArcGis 10.3, dengan metode Average Nearest Neighbour. Metode ini menentukan nilai tetangga terdekat berdasarkan jarak antar titik dalam satu layer dan luas area kajian. Nilai tetangga terdekat diperoleh dari perbandingan nilai rerata observasi dengan nilai rerata ekspektasi, sedangkan yang menjadi indikator dalam penentuan jenis pola adalah nilai $z$-score (Kurniati dkk, 2016). Terdapat tiga jenis pola persebaran, yakni mengelompok, seragam, dan acak. Pola persebaran mengelompok (clustered) ditunjukkan dengan nilai $z$-score yang negatif (-). Pola persebaran seragam (dispered) ditunjukkan dengan nilai $z$-score yang semakin besar dan positif (+).Pola persebaran acak (random) ditunjukkan dengan nilai $z$-score 0 atau mendekati 0 . Pola sebaran mataair di Kecamatan Dukun menurut analisis tetangga terdekat termasuk ke dalam pola mengelompok. Hal tersebut didasarkan pada nilai " $\mathrm{p}$ " dalam significant leve/0,01 dan nilai $z$-score kurang dari $-2,58$. Peta sebaran mataair dan grafik hasil analisis tetangga terdekat ditunjukkan oleh Gambar 2.
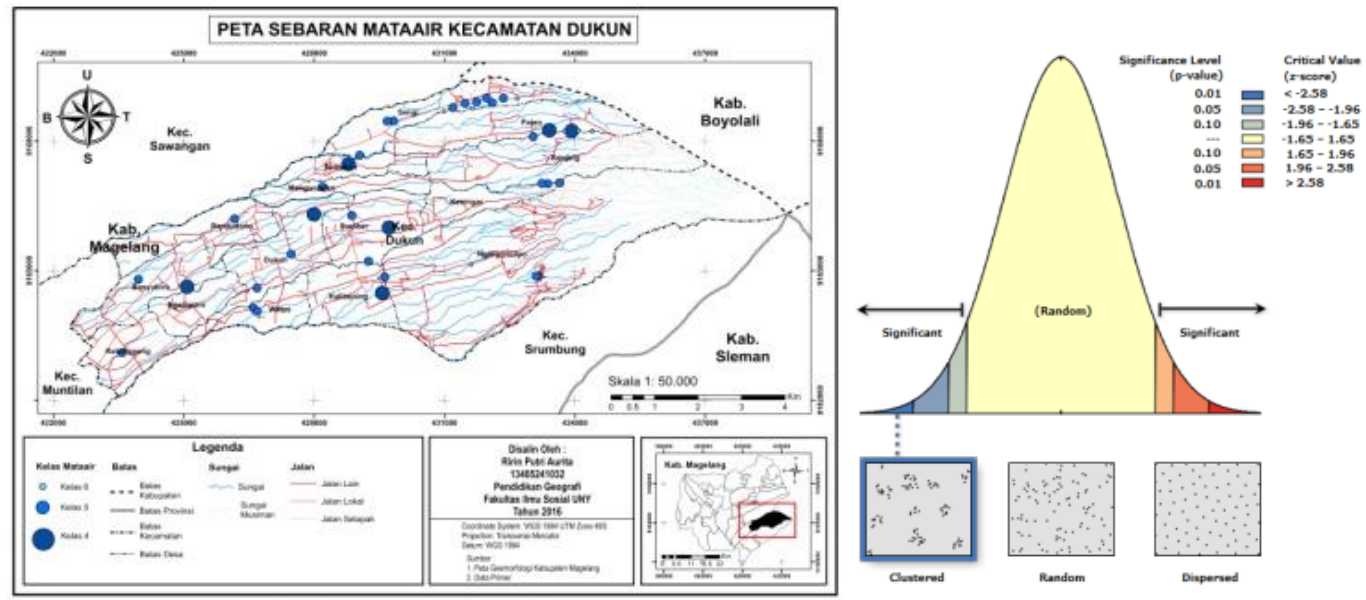

Gambar 2. Sebaran Mataair Kecamatan Dukun dan Grafik Hasil Analisis Tetangga Terdekat

\section{Potensi dan Pemanfaatan Mataair}

Terdapat 33 mataair yang digunakan untuk memenuhi kebutuhan air rumah tangga. Mataair untuk kebutuhan air rumah tangga dengan debit tertinggi terdapat pada Dusun Dukuhan, Desa Sumber dengan debit 3,819 liter per detik. Mataair untuk kebutuhan air rumah tangga dengan debit paling kecil terdapat pada Dusun Grawah, Desa Ngadipuro dengan debit 0,16 liter per detik. Rata-rata besar debit mataair dari 33 mataair yang diteliti di Kecamatan Dukun untuk memenuhi kebutuhan air rumah tangga adalah 1,6264 liter per detik.

Di Kecamatan Dukun hanya terdapat 4 desa yang menggunakan air dari sumber mataair untuk mengairi lahan pertaniannya. Dari 4 desa tersebut, diambil 8 mataair dari 
yang dikaji potensi dan imbangannya untuk memenuhi kebutuhan air irigasi. Mataair untuk memenuhi kebutuhan air irigasi dengan debit terbesar adalah mataair yang terletak di Sungai Trinsing dengan debit 16 liter per detik yang digunakan oleh Desa Paten dalam mencukupi kebutuhan air lahan pertaniannya. Mataair untuk kebutuhan air irigasi dengan debit terkecil yakni 12 liter per detik adalah mataair yang digunakan oleh Desa Kalibening dan Krinjing untuk mencukupi kebutuhan air lahan pertaniannya. Rata-rata besar debit 8 mataair yang digunakan untuk kebutuhan air irigasi di Kecamatan Dukun adalah sebesar 13,875 liter per detik.

Nilai kebutuhan air konsutif (CWR) untuk pola tanam padi-padi-palawija di daerah penelitian berkisar antara 28,814 $\mathrm{mm}$ per 0,5 bulan hingga 133,682 $\mathrm{mm}$ per 0,5 bulan. Nilai CWR yang tertinggi terjadi pada bulan Mei II yaitu sebesar 133,682 mm per 0,5 bulan, yakni pada saat tanaman padi memasuki tahap pertumbuhan generatif. Tahap pertumbuhan generatif pada tanaman padi adalah tahap tanaman padi tumbuh dewasa dan mulai berbuah atau sedang menuju masa panen. Hal ini menyebabkan pada tahap pertumbuhan generatif inilah tanaman padi membutuhkan lebih banyak air daripada tahap-tahap pertumbuhan sebelumnnya. Nilai kebutuhan air terendah terjadi pada bulan September II yaitu pada saat tanaman palawija memasuki masa masak tanaman dengan kebutuhan air sebesar $28,814 \mathrm{~mm}$ per 0,5 bulan. Tumbuhan palawija termasuk ke dalam jenis tanaman yang tidak membutuhkan banyak air, apalagi pada saat fase berbuah atau masak, sehingga nilai CWR terendah terjadi pada bulan September II. Besarnya kebutuhan air konsumtif tanaman dari masing-masing pola pergiliran tanaman selanjutnya akan digunakan untuk menghitung air di areal pertanian Farm Water Requirement (FWR) di masing-masing daerah irigasi.

Kebutuhan air di petak sawah (FWR) adalah jumlah air yang digunakan oleh tanaman ditambah dengan kehilangan air di areal pertanian, berupa pengaliran permukaan, perkolasi, dan evapotranspirasi. Besarnya kebutuhan air di petak sawah dihitung menggunakan empat parameter, yakni nilai kebutuhan air konsumtif (CWR), penggenangan, penjenuhan, dan perkolasi. Khusus untuk menentukan besarnya kebutuhan air untuk tanaman palawija tidak menggunakan parameter penggenangan, hanya kebutuhan air konsumtif (CWR), penjenuhan, dan perkolasi. Hasil perhitungan kebutuhan air di petak sawah daerah penelitian menunjukkan bahwa nilai Form Water Requirement (FWR) sebesar 91.814 hingga $213.682 \mathrm{~mm}$ per setengah bulan. Nilai FWR yang tertinggi terdapat pada bulan Mei II dan nilai FWR yang terendah terdapat pada bulan September II. Bulan Mei II mempunyai nilai FWR yang tertinggi dikarenakan pada saat bulan tersebut tanaman padi sedang memasuki tahap pertumbuhan generatif sehingga banyak memerlukan air. Bulan September II mempunyai nilai FWR yang paling rendah karena pada saat bulan tersebut tanaman palawija sudah masuk pada tahap masak sehingga tanaman palawija tidak memerlukan pasokan air yang banyak.

Hasil perhitungan kebutuhan air pada lahan pertanian (PWR) memperlihatkan bahwa di Desa Kalibening dan Ngargomulyo, kebutuhan air tertinggi terjadi pada bulan Mei II sebesar 0,766122 liter/detik dan kebutuhan air terendah terjadi pada bulan Maret II sebesar 0,098288 liter/detik. Kebutuhan air tertinggi terjadi pada bulan Mei II dikarenakan 
pada bulan tersebut tanaman padi sedang memasuki tahap pertumbuhan generatif sehingga membutuhkan banyak air untuk proses perkembangan menuju tahap pembungaan. Kebutuhan air terendah terjadi pada bulan Maret II dikarenakan curah hujan efektif pada bulan tersebut cukup besar sehingga walaupun tanaman padi sedang memasuki tahap persemaian dan memerlukan banyak air, kebutuhan air tersebut dapat tercukupi dengan curah hujan. Hasil perhitungan kebutuhan air pada lahan pertanian (PWR) memperlihatkan bahwa di Desa Paten dan Krinjing, kebutuhan air tertinggi terjadi pada bulan Mei II sebesar 0,704015 liter/detikdan kebutuhan air terendah terjadi pada bulan Februari II sebesar 0,194531 liter/detik. Kebutuhan air tertinggi terjadi pada bulan Mei II dikarenakan pada bulan tersebut tanaman padi sedang memasuki tahap pertumbuhan generatif sehingga membutuhkan banyak air untuk proses perkembangan menuju tahap pembungaan. Kebutuhan air terendah terjadi pada bulan Februari II dikarenakan pada bulan tersebut tanaman padi sedang memasuki tahap garapan dan pemindahan bibit sehingga tidak membutuhkan air dalam kapasitas besar. Di Desa Paten dan Krinjing pada bulan Desember II, Januari II, dan September II terjadi surplus air. Pada bulan Desember II terjadi surplus air sebesar 0,11186 liter/detik.

Pada hasil analisa imbangan air irigasi dengan mataair di Desa Kalibening menunjukkan bahwa sebagian besar fase tanaman mengalami kelebihan air untuk luas area 12 hektar. Kelebihan air tertinggi terjadi pada bulan September IIdengan nilai 15,17490 liter/detik. Hal tersebut dikarenakan pada bulan September IIterjadi kelebihan air pada lahan pertanian (PWR) sebesar 3,17496 liter/detik ditambah dengan debit mataair sebesar 12 liter/detik. Sedangkan kelebihan air terendah terjadi pada bulan Mei II dengan nilai sebesar 1,147693 liter/detik.

Hasil analisa imbangan air irigasi dengan mataair di Desa Ngargomulyo menunjukkan bahwa sebagian besar fase tanaman mengalami kelebihan air untuk luas area 20,5 hektar. Kelebihan air tertinggi terjadi pada bulan September II dengan nilai 21,00389 liter/detik. Hal tersebut dikarenakan pada bulan September II terjadi kelebihan air pada lahan pertanian (PWR) sebesar 5,42389liter/detik ditambah dengan debit mataair sebesar 15,58 liter/detik. Sedangkan kelebihan air terendah terjadi pada bulan Mei II dengan nilai sebesar 1,147693 liter/detik.

Hasil analisa imbangan air irigasi dengan mataair di Dusun Paten menunjukkan adanya bulan yang kekurangan air dan kelebihan air untuk luas area 68 hektar. Kelebihan air tertinggi terjadi pada bulan September I dengan nilai 34,09913 liter/detik. Sedangkan bulan yang mengalami kekurangan air terjadi pada bulan Mei II dengan nilai kekurangan sebesar 8,0963 liter/detik. Kebutuhan air total pada bulan Mei II adalah sebesar 52,0963 liter/detik sedangkan debit mataair hanya 44 liter/detik. Hasil analisa imbangan air irigasi dengan mataair di Dusun Bandung, Desa Paten memperlihatkan bahwa terdapat bulan yang menngalami kekurangan dan kelebihan air pada area pertanian seluas 66,5 hektar. Kelebihan air tertinggi terjadi pada bulan September I dengan nilai 18,31753 liter/detik. Sedangkan bulan yang mengalami kekurangan air terjadi pada bulan Mei II dengan nilai sebesar 22,9471 liter/detik. Kebutuhan air total pada bulan Mei II adalah sebesar 50,94711liter/detik sedangkan debit mataair hanya 44 liter/detik. 
Pada hasil analisa imbangan air irigasi dengan mataair di Desa Krinjing menunjukkan adanya bulan yang kekurangan air dan kelebihan air untuk luas area 13,5 hektar. Kelebihan air tertinggi terjadi pada bulan September I dengan nilai 10,03439 liter/detik. Sedangkan kelebihan air terendah terjadi pada bulan Mei II dengan nilai sebesar 1,657353 liter/detik. Secara keseluruhan, imbangan mataair untuk irigasi pada empat Desa di Kecamatan Dukun tercukupi. Terdapat dua desa, yakni Desa Kalibening

\section{Kualitas Fisika dan Kimia Mataair}

Dalam penelitian ini, terdapat dua mataair yang diteliti kualitas airnya berdasarkan parameter fisika dan kimia sesuai dengan baku mutu air minum menurut Peraturan Menteri Kesehatan Republik Indonesia Nomor 492 Tahun 2010. Kualitas fisika dan kimia mataair pada bentuklahan dataran kaki gunungapi yang diambil di Desa Keningar dan dataran fluvial gunungapi yang diambil di Desa Wates sesuai dan memenuhi persyaratan kualitas air minum menurut Permenkes RI Nomor 492 Tahun 2010 (Tabel 3).

Tabel 3. Kualitas Fisik dan imia Mataair

\begin{tabular}{|l|l|l|l|}
\hline \multicolumn{1}{|c|}{ Parameter } & \multicolumn{1}{|c|}{ Batas Maksimal } & \multicolumn{1}{c|}{ Desa Keningar } & \multicolumn{1}{c|}{ Desa Wates } \\
\hline Bau & tidak berbau & tidak berbau & tidak berbau \\
\hline Warna & $15 \mathrm{TCU}$ & $2 \mathrm{TCU}$ & $1 \mathrm{TCU}$ \\
\hline Total Zat Padat Terlarut & $500 \mathrm{mg} / \mathrm{L}$ & $123 \mathrm{mg} / \mathrm{L}$ & $114 \mathrm{mg} / \mathrm{L}$ \\
\hline Kekeruhan & $5 \mathrm{NTU}$ & $1 \mathrm{NTU}$ & $<1 \mathrm{NTU}$ \\
\hline Rasa & tidak berasa & tidak berasa & tidak berasa \\
\hline Suhu & $\begin{array}{l}\text { selisih } 3^{\circ} \mathrm{C} \\
\text { dgn suhu udara }\end{array}$ & $\begin{array}{l}23-25,2^{\circ} \mathrm{C} \\
\text { suhu udara } 26^{\circ} \mathrm{C}\end{array}$ & $\begin{array}{l}24-25,2^{\circ} \mathrm{C} \\
\text { suhu udara } 26^{\circ} \mathrm{C}\end{array}$ \\
\hline Alumunium & $0,2 \mathrm{mg} / \mathrm{L}$ & $0,0141 \mathrm{mg} / \mathrm{L}$ & $0,0265 \mathrm{mg} / \mathrm{L}$ \\
\hline Besi (Fe) & $0,3 \mathrm{mg} / \mathrm{L}$ & $0,0162 \mathrm{mg} / \mathrm{L}$ & $0,0162 \mathrm{mg} / \mathrm{L}$ \\
\hline Kesadahan & $500 \mathrm{mg} / \mathrm{L}$ & $78 \mathrm{mg} / \mathrm{L}$ & $76 \mathrm{mg} / \mathrm{L}$ \\
\hline Klorida $(\mathrm{Cl})$ & $250 \mathrm{mg} / \mathrm{L}$ & $13,5 \mathrm{mg} / \mathrm{L}$ & $10 \mathrm{mg} / \mathrm{L}$ \\
\hline Mangan & $0,4 \mathrm{mg} / \mathrm{L}$ & $<0,01 \mathrm{mg} / \mathrm{L}$ & $<0,01 \mathrm{mg} / \mathrm{L}$ \\
\hline pH & $6,5-7$ & 6,5 & 6,4 \\
\hline Seng (Zn) & $3 \mathrm{mg} / \mathrm{L}$ & $<0,0083 \mathrm{mg} / \mathrm{L}$ & $<0,0083 \mathrm{mg} / \mathrm{L}$ \\
\hline Sulfat (SO $\left.{ }_{4}\right)$ & $250 \mathrm{mg} / \mathrm{L}$ & $22 \mathrm{mg} / \mathrm{L}$ & $18 \mathrm{mg} / \mathrm{L}$ \\
\hline Tembaga & $2 \mathrm{mg} / \mathrm{L}$ & $0,0069 \mathrm{mg} / \mathrm{L}$ & $0,0069 \mathrm{mg} / \mathrm{L}$ \\
\hline Amonia & $1,5 \mathrm{mg} / \mathrm{L}$ & $0,0003 \mathrm{mg} / \mathrm{L}$ & $0,0003 \mathrm{mg} / \mathrm{L}$ \\
\hline Arsen $(A s)$ & $0,01 \mathrm{mg} / \mathrm{L}$ & $<0,005 \mathrm{mg} / \mathrm{L}$ & $<0,005 \mathrm{mg} / \mathrm{L}$ \\
\hline Fluorida $(\mathrm{F})$ & $1,5 \mathrm{mg} / \mathrm{L}$ & $0,3287 \mathrm{mg} / \mathrm{L}$ & $0,2124 \mathrm{mg} / \mathrm{L}$ \\
\hline Total Krom & $0,05 \mathrm{mg} / \mathrm{L}$ & $<0,0213 \mathrm{mg} / \mathrm{L}$ & $<0,021 \mathrm{mg} / \mathrm{L}$ \\
\hline
\end{tabular}




\begin{tabular}{|l|l|l|l|}
\hline Kadmium & $0,003 \mathrm{mg} / \mathrm{L}$ & $0,0004 \mathrm{mg} / \mathrm{L}$ & $0,0008 \mathrm{mg} / \mathrm{L}$ \\
\hline Nitrit & $3 \mathrm{mg} / \mathrm{L}$ & $0,0061 \mathrm{mg} / \mathrm{L}$ & $0,0036 \mathrm{mg} / \mathrm{L}$ \\
\hline Nitrat & $50 \mathrm{mg} / \mathrm{L}$ & $1,06 \mathrm{mg} / \mathrm{L}$ & $10,64 \mathrm{mg} / \mathrm{L}$ \\
\hline Sianida & $0,07 \mathrm{mg} / \mathrm{L}$ & tdk memiliki & tdk memiliki \\
\hline
\end{tabular}

Dua mataair yang diteliti berasal dari dua bentuklahan yang berbeda, yakni bentuklahan dataran kaki gunungapi dan dataran fluvial. Mataair yang berasal dari bentuk lahan dataran kaki gunung api diambil di Desa Keningar pada ketinggian 945 mdpal dengan titik koordinat 433379 mU dan 9167006 mT. Mataair ini merupakan mataair bertipe artesis yang mengalir sepanjang tahun (perennial). Mataair di Desa Keningar ini termasuk ke dalam mataair kelas 5 karena memiliki debit 2,43 liter/detik. Mataair yang berasal dari bentuk lahan dataran fluvial gunungapi diambil di Desa Wates pada ketinggian 522,12 mdpal dengan titik koordinat $426602 \mathrm{mU}$ dan $9164132 \mathrm{mT}$. Mataair ini merupakan mataair bertipe kontak yang mengalir sepanjang tahun (perennial). Mataair di Desa Wates ini termasuk ke dalam mataair kelas 5 karena memiliki debit 1,94 liter/detik.

\section{SIMPULAN}

Pola sebaran mataair di Kecamatan Dukun menurut analisis tetangga terdekat termasuk ke dalam pola mengelompok. Terdapat 33 mataair untuk kebutuhan air rumah tangga dan 8 mataair untuk kebutuhan air irigasi. Debit mataair terendah 0,16 liter/detik dan debit tertinggi 16 liter/detik. Rata-rata debit mataair untuk kebutuhan air rumah tangga adalah 1,6 liter/detik dan mataair untuk irigasi adalah 13,88 liter/detik. Rata-rata imbangan air untuk kebutuhan air rumah tangga surplus. Pemanfaatan mataair untuk irigasi secara keseluruhan juga tercukupi, namun terdapat bulan yang mengalami kekurangan air yakni pada bulan Mei II di Dusun Paten dan Dusun Bandung, Desa Paten. Berdasarkan persyaratan kualitas fisik dan kimia air minum menurut Permenkes RI Nomor 492 Tahun 2010 mataair di Desa Keningar dan Desa Wates sesuai dan memenuhi persyaratan.

\section{UCAPAN TERIMA KASIH}

Tulisan ini merupakan bagian dari penelitian tugas akhir skripsi yang berjudul Karakteristik Mataair Kaki Lereng Gunung Merapi dan Pemanfaatannya di Kecamatan Dukun Kabupaten Magelang. Dalam kesempatan ini penulis mengucapkan terima kasih yang sebesar-besarnya kepada berbagai pihak yang telah membantu dalam proses penelitian, khususnya kepada pembimbing tugas akhir.

\section{DAFTAR PUSTAKA}

Ashari, A. 2014. Distibusi Spasial Mataair Kaitannya dengan Keberadaan Situs Arkeologi di Kaki Lereng Timur Gunungapi Sindoro Antara Parakan dan Ngadirejo Kabupaten Temangung. Posiding Seminar Nasional Geografi Untukmu Negeri. Fakultas Ilmu Sosial Universitas Negeri Yogyakarta 2014. 
Badan Pusat Statistik. 2015. Kecamatan Dukun dalam Angka Tahun 2015.

Kurniati, E. 2016. Nice Tutorial SIG Lanjut: Sistem Informasi Geografis Tingkat Lanjut. Billion Technology: Yogyakarta.

Santosa, L.W. 2006. Kajian Hidrogeomorfologi Mataair di Sebagian Lereng Barat Gunungapi Lawu. Forum Geografi 20 (1): 68-85

Peraturan Menteri Kesehatan Nomor 492 Tahun 2010 tentang Persyaratan Kualitas Air Minum 